\title{
Enhancement of the Gelling Properties of Sardine Surimi with Transglutaminase and Optimization of its Activity Using Response Surface Methodology
}

\author{
Imen Zaghbib ${ }^{1 *}$, Soumaya Arafa ${ }^{1}$, Manuel Félix², Mnasser Hassouna ${ }^{1}$ and Alberto Romero ${ }^{2}$
}

${ }^{1}$ Ecole Supérieure des Industries Alimentaires de Tunis, Unité de Recherche "Bioconservation et Valorisation des Produits Agroalimentaires", Tunis, Tunisie ${ }^{2}$ Departamento de Ingeniería Química, Facultad de Química, Universidad de Sevilla, Sevilla, Espaňa

\begin{abstract}
In order to improve the gelling properties of sardine surimi gel and to determine the maximum activity range of microbial transglutaminase (MTGase), we investigated the characteristics of surimi gel as a function of MTGase concentration, as well as temperature and reaction time, using the response surface methodology. Specifically, we assessed the following mechanical and physicochemical characteristics of the gel: rheological properties, disulphide bond and total sulfhydryl group content, and waterholding capacity. Our results demonstrated that temperature and enzyme concentration had more influence than reaction time on all dependent variables, incorporation of MTGase markedly ameliorated all the responses. The optimal properties were predicted to be obtained by employing the optimised setting conditions as follows: a concentration of MTGase of $10 \mathrm{~g} / \mathrm{kg}$ of surimi at $45^{\circ} \mathrm{C}$ for $1 \mathrm{~h}$. All the mathematical models derived for the various responses were found to be a good fit to predict the data.
\end{abstract}

Keywords: Microbial transglutaminase; Setting; Sardine surimi; Gelling; Response surface methodology

\section{Introduction}

In recent years, the increasing demand for "fresh food products" worldwide has prompted attempts to better understand and study restructured product. The addition of ingredients or additives can lead to improve these products in order to make them with new textural properties and/or a new appearance. Most of these products, particularly seafood analogues, are made from surimi of different sources of protein. Surimi is a structure of myofibrillar protein concentrates obtained from fish muscle, with a high commercial value and a wide range of applications in seafood production [1]. Given the limited availability of white muscle fish due to their overexploitation, it would be desirable to use lower-quality surimi from other species and to improve it by further processing [2]. Therefore, more attention has been paid to dark muscle fish species as an alternative raw material [3-5].

Among all dark-fleshed fish species, sardine was one of the most abundant species caught in Tunisia. The use of this small pelagic fish for surimi production is a promising way and an alternative to revalue and convert underutilized fish protein resources into foods of premium quality, particularly protein gel-based products. However, the characteristics of surimi gel depend on the properties of the myofibrillar proteins, and these are determined by the species and freshness of the fish, as well as the processing parameters [6].

Small pelagic fish species, such as sardine, produce surimi with poor gel characteristics due to the high content of dark muscle, comprising a considerable amount of lipids and sarcoplasmic proteins $[7,8]$. The presence of sarcoplasmic proteins of dark muscle has often been cited as one of the reasons for the poorer gelation properties of dark muscle fish compared to light muscle fish [9]. In this context, microbial transglutaminase (MTGase) has been studied as a means of improving the textural characteristics and mechanical properties of fish as well as meat products [10]. MTGase induces the formation of $\varepsilon$-( $\gamma$-glutamyl) lysine cross-link in the proteins via acyl transfer between the $\varepsilon$-amino groups of a lysine residue and $\gamma$-amide group of a glutamine residue [11]. The reactions promoted by the enzyme create profound changes in the proteins in food matrices, which results in the improvement of textural properties and stability in terms of temperature, syneresis, emulsifying properties, gelation and water-holding capacity (WHC), without changing the $\mathrm{pH}$, colour, flavour or nutritional quality of food, and may even render it more nutritious due to the possibility of adding essential amino acids [12]. However, the efficiency of MTGase in improving gelation properties of proteins depends on many factors, including the amount of MTGase, type of fish, and fat content [13-15].

In addition to the gel enhancer used, setting response is an important step in the formation of surimi gel that contributes to the different gelling properties. Setting or suwari is a treatment prior to cooking, which involves pre-incubation of salted surimi paste, generally at temperatures between $0^{\circ} \mathrm{C}$ and $40^{\circ} \mathrm{C}$ [16]. This results in the formation of a myosin network through cross-linking induced by endogenous transglutaminase (TGase) [17,18]. Considering this, a study to determine the optimal conditions for setting, using MTGase, can be based on analysing the relationship between enzyme concentration, time and temperature.

To determine the best conditions for TGase activity in foods, several authors have used the response surface methodology (RSM) [19-21]. This methodology develops a suitable experimental design by collecting statistical and mathematical tools that are useful for the modelling and analysis of problems in which a response of interest is influenced by several variables, with the objective of optimizing the response [22]. The RSM involves full factorial research to explore

*Corresponding author: Imen Zaghbib, Ecole Supérieure des Industries Alimentaires de Tunis, Unité de Recherche "Bioconservation et Valorisation des Produits Agroalimentaires", 1003 El Khadra, Tunis, Tunisie, Tel: +21692723221; E-mail: zaghbibimen@gmail.com

Received May 10, 2016; Accepted May 27, 2016; Published June 03, 2016

Citation: Zaghbib I, Arafa S, Félix M, Hassouna M, Romero A (2016) Enhancement of the Gelling Properties of Sardine Surimi with Transglutaminase and Optimization of its Activity Using Response Surface Methodology. J Food Process Technol 7: 594. doi:10.4172/2157-7110.1000594

Copyright: @ 2016 Zaghbib I, et al. This is an open-access article distributed under the terms of the Creative Commons Attribution License, which permits unrestricted use, distribution, and reproduction in any medium, provided the original author and source are credited. 
simultaneous, systematic and efficient variations in the important components, identifying potential interactions and higher-order effects, and thereby determining the optimal operational conditions [23]. Although MTGase has been successfully used for improving the gelation properties of surimi, no information has been reported regarding the use of MTGase in surimi gel from dark-fleshed fish species, such as sardine. The aim of this study was to use sardine (Sardina pilchardus) resource and transform it from low-valued fish to high-value-added product "surimi gel", to evaluate the effects of MTGase in sardine surimi gel and to optimize the conditions for enzyme activity during setting (concentration, temperature and time) using the RSM.

\section{Materials and Methods}

\section{Microbial transglutaminase}

MGTase from Streptoverticillium mobaraense was supplied by Ajinomoto USA, INC. (Teaneck, NJ, USA). Enzyme activity reported by the supplier was 100 units/g dry weights. The enzyme powder consisted of $99 \%$ maltodextrin and $1 \%$ enzyme by mass.

\section{Surimi paste preparation}

In order to prepare surimi by the conventional washing process [24], fresh sardine (Sardina pilchardus) was purchased from a fish market in Tunisia. Fish were headed, eviscerated and washed. Skin and bones were removed by hand in the laboratory. Fillets were minced in a meat mincer (TC-32 EL/80 Tre Spade, Torino, Italy). Fish mince was washed with cold water $\left(4^{\circ} \mathrm{C}\right)$ using a water-to-mince ratio of $3: 1(\mathrm{v} / \mathrm{w})$. The mixture was stirred gently for $10 \mathrm{~min}$ and the washed mince was filtered with a layer of nylon screen. This washing process was performed thrice. Finally, the washed mince was dewatered by centrifugation at a speed of $700 \times g$ for $15 \mathrm{~min}$ at $4^{\circ} \mathrm{C}$ (Model CE $21 \mathrm{~K}$, Grandimpianti, Belluno, Italy). A cryoprotectant mixture was added to the washed mince ( $4 \%$ sorbitol and $4 \%$ sucrose $\mathrm{w} / \mathrm{w}$ ). Surimi was packed into polyethylene bags $(250 \mathrm{~g})$ and stored at $-20^{\circ} \mathrm{C}$ until used for gel preparation. The storage time did not exceed 1 month.

\section{Surimi gel preparation}

Frozen surimi samples were partially thawed at $4^{\circ} \mathrm{C}$, then cut into small pieces and chopped with $2.5 \% \mathrm{NaCl}(\mathrm{w} / \mathrm{w})$ for $3 \mathrm{~min}$. MTGase was then added to the surimi paste and the mixture was chopped for another $5 \mathrm{~min}$. Then moisture content of the surimi was adjusted to $80 \%$ with iced water and the chopping was continued for $15 \mathrm{~min}$. For the entire chopping process, the temperature was kept below $10^{\circ} \mathrm{C}$.

The paste was stuffed into stainless steel tubes (diameter $=2.5 \mathrm{~cm}$; length $=15 \mathrm{~cm}$ ), inner wall of which was coated with a film of vegetable oil to prevent gel adhesion. Both ends of the tubes were sealed tightly. The paste samples were allowed to set and then heated at $90^{\circ} \mathrm{C}$ for 20 min. The gel samples were cooled rapidly in iced water and kept at $4^{\circ} \mathrm{C}$ overnight until analysis.

\section{Rheological measurements}

Linear dynamic viscoelasticity measurements were determined using a controlled-stress rheometer (AR2000) from TA Instruments (New Castle, DE, USA) equipped with two parallel plates $(40 \mathrm{~mm}$ diameter) with rough surfaces, setting a gap between plates of $0.5 \mathrm{~mm}$ [25]. Before measurement, the gels were tempered at room temperature and cut to size, namely, to the same diameter as that of the plate and at a thickness of $0.5 \mathrm{~mm}$. Samples were covered with a thin film of petroleum jelly to avoid evaporation. All determinations were carried out at least in triplicate.

Stress sweep tests: In order to determine the linear viscoelastic (LVE) region, stress sweeps were conducted at $6.28 \mathrm{rad} / \mathrm{s}$ with a constant temperature at $25^{\circ} \mathrm{C}$. The shear stress $(\sigma)$ of the input signal was programmed from 1 to $1000 \mathrm{~Pa}$.

Frequency sweep tests: Frequency sweep tests were carried out at different frequencies ranging from 10 to $0.1 \mathrm{~Hz}$ under a constant shear strain amplitude $(\gamma=0.2 \%)$ within the LVE range. Storage modulus $\left(\mathrm{G}^{\prime}\right)$, loss modulus $\left(\mathrm{G}^{\prime}\right)$ and loss tangent $(\tan \delta)$ were recorded at $1 \mathrm{~Hz}$.

\section{Disulphide bonds}

The disulphide bond (DB) content was determined using a 2-nitro5-thiosulphobenzoate assay method [26]. Freshly prepared 2-nitro5 -thiosulphobenzoate assay solution $(3 \mathrm{ml})$ was added to the protein solution $(0.5 \mathrm{ml})$ and the mixture was allowed to set in the dark at room temperature $\left(26^{\circ} \mathrm{C}\right.$ to $\left.28^{\circ} \mathrm{C}\right)$ for $25 \mathrm{~min}$. Absorbance was measured at $412 \mathrm{~nm}$. DB content was calculated using the molar extinction coefficient of 13,900 M-1 $\mathrm{cm}^{-1}$ using a Genesys-20 spectrophotometer (Thermo Scientific, USA).

\section{Total sulfhydryl group content}

The total sulfhydryl (TSH) content was determined using 5,5'-dithio-bis (2-nitrobenzoic acid) method [27] with some modifications. Samples ( $70 \mu \mathrm{L}$ of protein solution) were homogenised with $1 \mathrm{ml}$ of solubilizing buffer $(20 \mathrm{mMTris}-\mathrm{HCl}, 8 \mathrm{M}$ urea, $10 \mathrm{mM}$ EDTA, pH 8.0). An aliquot $(100 \mu \mathrm{L})$ of Ellman's reagent was added. The mixture was incubated in the dark at room temperature for $30 \mathrm{~min}$. As for DB content, the amount of TSH was measured at $412 \mathrm{~nm}$ with a molar extinction coefficient of $13,600 \mathrm{M}^{-1} \mathrm{~cm}^{-1}$ using a Genesys-20 spectrophotometer (Thermo Scientific, USA).

\section{Water-holding capacity}

WHC was evaluated by a centrifuge method [28]. It was expressed as the percentage of the initial water remaining in the sample after centrifugation. Each value is the mean (standard deviation) of at least four measurements.

\section{Response surface methodology}

In order to determine the best conditions for the production of sardine surimi gel, Response surface methodolgy (RSM) was applied to derive mathematical models to estimate the effects design and the interactions of the independent variables: enzyme concentration $\left(x_{1}\right)$, temperature $\left(x_{2}\right)$ and incubation time $\left(x_{3}\right)$ on the storage modulus $\left(G^{\prime} y_{1}\right)$, loss modulus $\left(G^{\prime \prime} y_{2}\right)$, disulphide bond content (DB $\left.y_{2}\right)$, total sulfhydryl group content (TSH $y_{4}$ ) and water-holding capacity (WHC $y_{5}$ ) of surimi gel samples which were the selected responses for this research.

The experimental design followed a second-order factorial structure [29] with 4 replications at the centre point to estimate the experimental error, leading to 30 experiments, carried out in a random order and in triplicate.

Table 1 presents the variables used in the optimization of the setting process during sardine surimi production including fixed variables at usual values.

In order to estimate the response, an empirical model was constructed based on a second-order polynomial (1): 
Citation: Zaghbib I, Arafa S, Félix M, Hassouna M, Romero A (2016) Enhancement of the Gelling Properties of Sardine Surimi with Transglutaminase and Optimization of its Activity Using Response Surface Methodology. J Food Process Technol 7: 594. doi:10.4172/2157-7110.1000594

Page 3 of 8

\begin{tabular}{|c|c|c|c|}
\hline \multicolumn{2}{|c|}{ Variables } & Unit & Nomenclature \\
\hline \multirow{3}{*}{ Independent variables } & Enzyme concentration & $\mathrm{g} / \mathrm{Kg}$ & $\mathrm{x} 1$ \\
\hline & Temperature & ${ }^{\circ} \mathrm{C}$ & $\mathrm{x} 2$ \\
\hline & Incubation time & $\mathrm{h}$ & $\mathrm{x} 3$ \\
\hline \multirow{5}{*}{ Dependent variables } & $G^{\prime}$ & $\mathrm{Pa}$ & y1 \\
\hline & G” & $\mathrm{Pa}$ & y2 \\
\hline & Disulphide bonds & $\%$ & y3 \\
\hline & Total sulfhydryl group & $\mathrm{mmol} / \mathrm{g}$ proteins & y4 \\
\hline & Water holding capacity & $\%$ & y5 \\
\hline
\end{tabular}

Table 1: Variables used for the experimental design.

$$
y=\beta_{0}+\sum_{i=1}^{k} \beta_{i} x_{i}+\sum_{i=1}^{k} \sum_{j=1}^{k} \beta_{i j} x_{i} x_{j}+\sum_{i=1}^{k} \beta_{i i} x_{i}^{2}
$$

Where, $y$ is the estimated response, $\beta_{0}$ the model constant, $\beta_{\mathrm{i}}$ the coefficients of the linear term, $\beta_{\mathrm{ii}}$ the coefficients of the quadratic term, $\beta_{\mathrm{ij}}$ the coefficients of interaction between the factors, $x_{i}$ and $x_{1}$ the design variables, $\mathrm{k}$ the number of factors, and $\mathrm{i}$ and $\mathrm{j}$ the coded factors of the system. The experiments were assessed using the Design-Expert software (Statease Inc., Minneapolis, USA, version 7.0). For each response, the coefficients were calculated by regression analysis and the significance of the derived model equation was determined using the analysis of variance (ANOVA).

\section{Results and Discussion}

\section{Parameter ranges studied}

The main effects and the interactions of MTGase concentration, temperature and reaction time during setting of sardine surimi were assessed using the RSM. Many researchers apply RSM as a mathematical modelling tool in bioprocess optimization [30,31]. By using RSM, process variables could be controlled together to result in maximum product properties with desired characteristics $[32,33]$.

Setting can be performed at low $\left(0^{\circ} \mathrm{C}\right.$ to $\left.4^{\circ} \mathrm{C}\right)$, medium $\left(25^{\circ} \mathrm{C}\right)$ or high $\left(40^{\circ} \mathrm{C}\right)$ temperatures [34], and the choice of temperature may lead to different gelling properties, since gel setting behaviour is fish species and temperature dependent. At low temperature, setting takes longer, and so it is not commonly implemented in industry. So far, high-temperature setting is more widely used in Thailand, given the shorter time required, but there is a risk of protein degradation, due to modori-inducing proteinase, which is generally active at 50 to $60^{\circ} \mathrm{C}$ [35]. Therefore, a medium-temperature setting may be considered the best option for manufacturers to obtain the highest gel quality with negligible proteolysis.

In line with this, we studied temperatures between $25^{\circ} \mathrm{C}$ and $45^{\circ} \mathrm{C}$, because $25^{\circ} \mathrm{C}$ is the temperature commonly recommended for setting in cold water species such as Alaska Pollock (Theragra chalcogramma) [36], while $45^{\circ} \mathrm{C}$ is the recommended maximum, to avoid the modori phenomenon in the range $50^{\circ} \mathrm{C}$ to $70^{\circ} \mathrm{C}$ [37]. Regarding reaction time, we collected data between $1 \mathrm{~h}$ and $5 \mathrm{~h}$, because it has been reported that MTGase is active for between $2 \mathrm{~h}$ and $5 \mathrm{~h}$ in Alaska pollock at $25^{\circ} \mathrm{C}$ [38].

The range for the variable enzyme concentration $(0 \mathrm{~g} / \mathrm{kg}-10 \mathrm{~g} / \mathrm{kg})$ was chosen according to the studies which deal with the improvement of the mechanical properties of surimi produced from striped mullet (Mugil cephalus) and silver carp (Hypophthalmichthys molitrix) respectively $[39,40]$.

\section{Dynamic viscoelasticity measurements}

The storage and loss modulus $\left(G^{\prime}\right.$ and $\left.G^{\prime}\right)$ were considered as responses, since research on surimi rheological properties has shown the importance of the viscoelastic moduli $G^{\prime}$ and $G^{\prime}$ in the nominal quality of surimi [41]. Moreover, the use of MTGase, through the cross-links it promotes, enables highly elastic and irreversible gels to be obtained in different substrates, even at relatively low protein concentrations $[42,43]$.

Table 2 summarizes the operational conditions tested as well as the experimental and predicted response values determined for the dependent variables obtained from this experimental design. It can be observed that the experimental values for storage modulus $G^{\prime}\left(y_{1}\right)$ varied over a wide range $(3121 \mathrm{~Pa}-63520 \mathrm{~Pa})$.

The analysis of the regression coefficients and the main experimental trends are presented in Table 3 . It can be concluded that temperature and enzyme concentration have the most influence on $G^{\prime}$, followed by the interaction between temperature and time. Using the models, it is possible to predict the results and plot them as a response surface in three-dimensional graphs. The response surface for $G^{\prime}\left(y_{1}\right)$ is illustrated in the Figure 1 which describes the dependence of $y 1$ on enzyme concentration and temperature at the different incubation times used. From the plot, it can be seen that increasing enzyme concentration and temperature allow us to reach higher values of $G^{\prime}$ at shorter times, but at longer times, high enzyme concentration and temperature lead to a decrease in $y_{1}$.

For loss modulus $G^{\prime}\left(y_{2}\right)$, a similar behaviour was observed, the experimental results varied within the wide range of 1845 to 13897 $\mathrm{Pa}$ (Table 2). Analysis of the regression coefficients and the main experimental trends suggest the same results as $G^{\prime}\left(y_{1}\right)$ (Table 3). Temperature and enzyme concentration have the most influence on $G^{\prime}$, followed by the interaction between temperature and time. The resulting variation pattern is shown in Figure 2 where MTGase concentration and temperature were the variables that most influenced the setting of sardine surimi gel.

\section{Disulfide bond and total sulfhydryl group content}

DB and TSH content were also used as responses because they are major parameters for evaluating the gelling properties of surimi. The presence of sulfhydryl groups in surimi is necessary for gel strengthening. High temperatures during heating led to further oxidation of sulfhydryl groups with a subsequent disulfide bond formation [44].

DB $\left(y_{3}\right)$ and TSH $\left(y_{4}\right)$ showed behaviour different to $y_{1}$ and $y_{2}$. The experimental results varied within the narrow ranges of $23.99 \%$ to $33.6 \%$ and 14.71 to $1.14 \mathrm{mmol} / \mathrm{g}$ proteins for DB and TSH, respectively. The most favourable conditions were defined by the maximum value of enzyme concentration, the highest value of temperature and the shortest time (experiment 28). Analysis of the regression coefficients for $y 3$ and $y 4$ showed that enzyme concentration did not significantly affect DB content. The variation of DB and TSH contents with 


\begin{tabular}{|c|c|c|c|c|c|c|c|c|c|c|c|c|c|}
\hline \multirow[t]{2}{*}{ Test } & \multicolumn{3}{|c|}{ Factors } & \multicolumn{5}{|c|}{ Experimental responses } & \multicolumn{5}{|c|}{ Predicted values } \\
\hline & $E$ & $\mathbf{t}$ & $\mathbf{T}$ & y1 & y2 & y3 & y4 & y5 & y1 & y2 & y3 & y4 & y5 \\
\hline 1 & 0 & 1 & 25 & 6692 & 2144 & 23.99 & 14.71 & 49.25 & 9501 & 3626 & 25.29 & 13.61 & 49.26 \\
\hline 2 & 0 & 3 & 25 & 8186 & 4874 & 29.46 & 10.26 & 50.73 & 7841 & 3062 & 26.93 & 11.71 & 50.65 \\
\hline 3 & 0 & 5 & 25 & 18602 & 4494 & 27.90 & 8.83 & 53.16 & 26153 & 6615 & 29.13 & 8.34 & 54.04 \\
\hline 4 & 0 & 1 & 35 & 17760 & 4915 & 29.56 & 8.17 & 53.82 & 15812 & 5452 & 29.36 & 8.73 & 53.43 \\
\hline 5 & 0 & 3 & 35 & 7080 & 4080 & 30.57 & 10.17 & 52.82 & 2753 & 2589 & 29.347 & 8.99 & 52.746 \\
\hline 6 & 0 & 5 & 35 & 19710 & 4816 & 29.36 & 7.36 & 54.63 & 9666 & 3845 & 29.88 & 7.77 & 54.06 \\
\hline 7 & 0 & 1 & 45 & 44242 & 12476 & 30.69 & 5.05 & 55.94 & 48641 & 12799 & 31.21 & 4.83 & 56.83 \\
\hline 8 & 0 & 3 & 45 & 21763 & 7578 & 27.89 & 7.84 & 53.15 & 24183 & 7638 & 29.53 & 7.24 & 54.07 \\
\hline 9 & 0 & 5 & 45 & 20213 & 6846 & 29.70 & 7.04 & 54.95 & 19697 & 6596 & 28.41 & 8.18 & 53.32 \\
\hline 10 & 5 & 1 & 25 & 16396 & 4353 & 26.56 & 10.17 & 50.82 & 12611 & 3704 & 25.68 & 11.58 & 50.77 \\
\hline 11 & 5 & 3 & 25 & 29630 & 5812 & 25.84 & 10.90 & 52.09 & 13209 & 3915 & 27.39 & 9.94 & 51.56 \\
\hline 12 & 5 & 5 & 25 & 24096 & 7830 & 29.44 & 7.29 & 54.70 & 33780 & 8244 & 29.66 & 6.83 & 54.37 \\
\hline 13 & 5 & 1 & 35 & 20363 & 7087 & 30.62 & 6.12 & 55.87 & 19704 & 5491 & 30.04 & 6.74 & 55.65 \\
\hline 14 & 5 & 3 & 35 & 3121 & 1921 & 30.65 & 7.08 & 54.91 & 8903 & 3404 & 30.09 & 7.26 & 54.37 \\
\hline 15 & 5 & 3 & 35 & 3263 & 3521 & 28.89 & 7.84 & 54.15 & 8903 & 3404 & 30.09 & 7.26 & 54.37 \\
\hline 16 & 5 & 3 & 35 & 9353 & 3144 & 30.49 & 6.24 & 55.75 & 8903 & 3404 & 30.09 & 7.26 & 54.37 \\
\hline 17 & 5 & 3 & 35 & 3333 & 1845 & 29.83 & 6.90 & 55.09 & 8903 & 3404 & 30.09 & 7.26 & 54.37 \\
\hline 18 & 5 & 5 & 35 & 20340 & 6079 & 30.71 & 7.02 & 51.97 & 18074 & 5436 & 30.70 & 6.30 & 55.10 \\
\hline 19 & 5 & 1 & 45 & 58330 & 13220 & 32.94 & 2.80 & 60.19 & 53314 & 12800 & 32.17 & 2.88 & 59.76 \\
\hline 20 & 5 & 3 & 45 & 28850 & 7262 & 30.54 & 6.19 & 55.80 & 31114 & 8415 & 30.57 & 5.55 & 56.41 \\
\hline 21 & 5 & 5 & 45 & 29230 & 7698 & 29.64 & 7.10 & 54.89 & 28887 & 8149 & 29.52 & 6.74 & 55.06 \\
\hline 22 & 10 & 1 & 25 & 11010 & 4658 & 25.14 & 11.59 & 50.40 & 16839 & 5120 & 25.69 & 10.67 & 50.71 \\
\hline 23 & 10 & 3 & 25 & 19703 & 4867 & 27.97 & 8.76 & 50.23 & 19695 & 6107 & 27.47 & 9.29 & 50.90 \\
\hline 24 & 10 & 5 & 25 & 47840 & 12573 & 30.79 & 5.95 & 54.04 & 42524 & 11212 & 29.82 & 6.44 & 53.11 \\
\hline 25 & 10 & 1 & 35 & 21926 & 7254 & 29.48 & 7.25 & 54.74 & 24712 & 6869 & 30.34 & 5.87 & 56.30 \\
\hline 26 & 10 & 3 & 35 & 14610 & 4610 & 30.93 & 5.81 & 55.18 & 16170 & 5558 & 30.46 & 6.65 & 54.42 \\
\hline 27 & 10 & 5 & 35 & 29243 & 7952 & 30.61 & 6.13 & 54.86 & 27599 & 8365 & 31.15 & 5.95 & 54.55 \\
\hline 28 & 10 & 1 & 45 & 63520 & 13897 & 33.60 & 1.14 & 62.85 & 59103 & 14141 & 32.76 & 2.05 & 61.12 \\
\hline 29 & 10 & 3 & 45 & 40846 & 11920 & 30.29 & 5.44 & 55.55 & 39162 & 10531 & 31.23 & 4.98 & 57.16 \\
\hline 30 & 10 & 5 & 45 & 36302 & 11214 & 30.41 & 6.31 & 55.68 & 39193 & 11040 & 30.25 & 6.43 & 55.22 \\
\hline
\end{tabular}

Table 2: Operational conditions assayed with the independent variables and their experimental and predicted responses.

\begin{tabular}{|c|c|c|c|c|c|}
\hline \multirow{2}{*}{ Co-efficients } & \multicolumn{5}{|c|}{ Response } \\
\cline { 2 - 6 } & $\mathbf{y 1}$ & $\mathbf{y 2}$ & $\mathbf{y 3}$ & $\mathbf{y 4}$ & $\mathbf{y 5}$ \\
\hline$\beta 0$ & 8902.69 & 3404.38 & 30.1 & 7.26 & 54.37 \\
\hline$\beta 1$ & 6708.44 & 1484.56 & 0.33 & -1.17 & 0.84 \\
\hline$\beta 2$ & 8952.28 & 2250.33 & 1.59 & -2.2 & 2.42 \\
\hline$\beta 3$ & -814.61 & -27.89 & 0.56 & -0.22 & -0.28 \\
\hline$\beta 11$ & 558.56 & 669.46 & -0.19 & 0.56 & -0.79 \\
\hline$\beta 22$ & 13259.06 & 2760.79 & -1.11 & 0.49 & -0.38 \\
\hline$\beta 33$ & 9986.4 & 2059.13 & 0.28 & -0.74 & 1.01 \\
\hline$\beta 12$ & 781.42 & -37.92 & 0.29 & 0.038 & 0.71 \\
\hline$\beta 13$ & 2258.17 & 775.75 & 0.073 & 0.26 & -0.6 \\
\hline$\beta 23$ & -11398.92 & -2298.08 & -1.66 & 2.16 & -2.07 \\
\hline
\end{tabular}

Table 3: Regression co-efficients for the response surface models in terms of coded units.

enzyme concentration and temperature at several incubation times are presented in Figures 3 and 4 respectively. Notably, using a long incubation time did not induce oxidation of sulfhydryl groups and produce a surimi gel with low DB.

\section{Water-holding capacity}

The last dependent variable considered as a response variable in this study was WHC, that is, the protein's ability to take up water and retain it within a protein matrix, e.g., beef or fish muscle or a protein gel, through protein-water interactions. Hence, WHC is closely linked to gelation, emulsification and foaming properties [42]. In myofibrillar proteins, WHC is inversely correlated with enzyme concentration beyond a certain threshold concentration, because the higher the enzyme concentration, the greater the number of inter- and intra-chain peptide cross-links and the weaker the protein-water interaction. Thus, the amount of enzyme added should be carefully evaluated because, in appropriate concentrations, MTGase yields stable gels with relatively high porosity that are able to immobilize water more efficiently. As a result of this increase in WHC, protein gels obtained have better textural properties, in terms of bond strength, stiffness, cohesion, chewability and elasticity $[45,46]$.

The experimental results of WHC varied within the narrow range of $49.25 \%$ to $62.85 \%$. Analysis of the main experimental trends and the values of coefficients listed in Table 3 suggest that temperature has the strongest influence on WHC, followed by enzyme concentration and the interaction between temperature and incubation time. The most favourable conditions were defined by the maximum value of enzyme concentration, the highest value of temperature and the shortest time (experiment 28). In Figure 5, it can be observed that the model predicts that an increase in temperature and enzyme concentration would make it possible to reach higher values of $y 5$ at short times, but that at long times, high temperatures lead to a decrease in $y_{5}$, so the effect of temperature and MTGase concentration are pronounced at shorter time.

\section{Model fitting}

It is important to assess the model fitted to ensure that it provides sufficiently close approximation to the results obtained under experimental conditions [47]. 


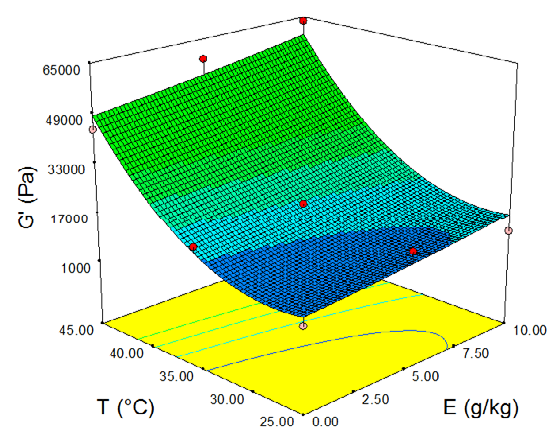

a

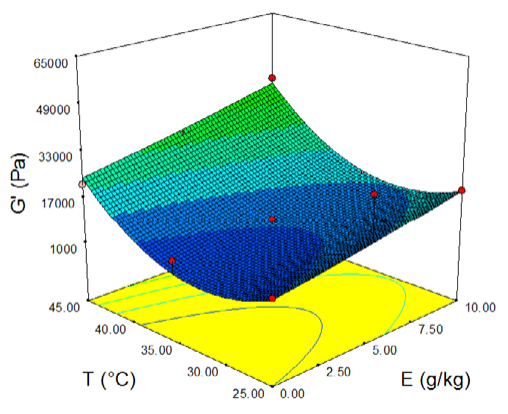

b

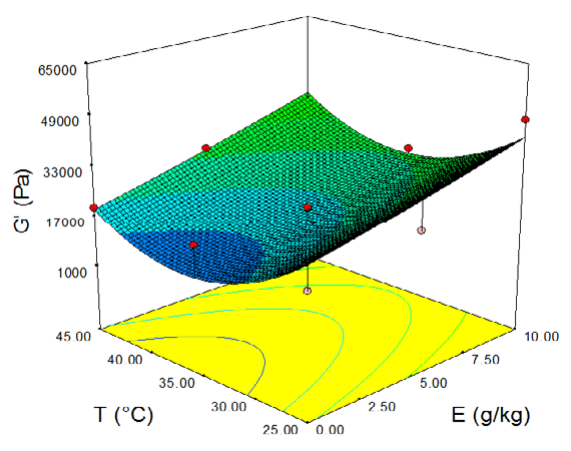

c

Figure 1: Response surface plots for the effects of temperature $\left({ }^{\circ} \mathrm{C}\right)$ and commercial enzyme concentration $(\mathrm{g} / \mathrm{kg})$ at different incubation times $(\mathrm{h})$ on $\mathrm{G}$ (Pa). $(1 \mathrm{a}) \mathrm{At}$ time $=1 \mathrm{~h},(1 \mathrm{~b})$ At time $=3 \mathrm{~h},(1 \mathrm{c})$ At time $=5 \mathrm{~h}$.

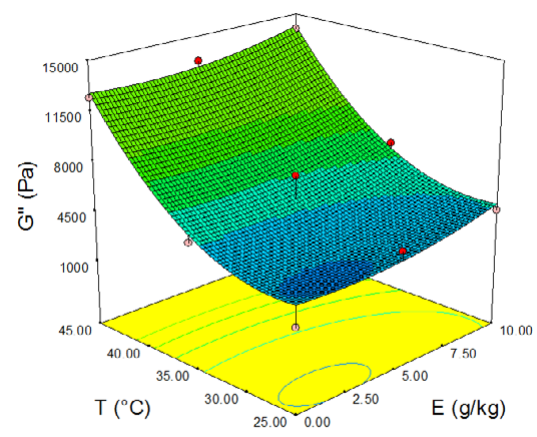

a

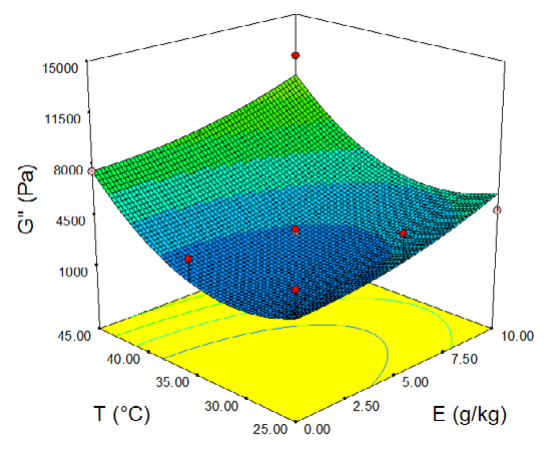

b

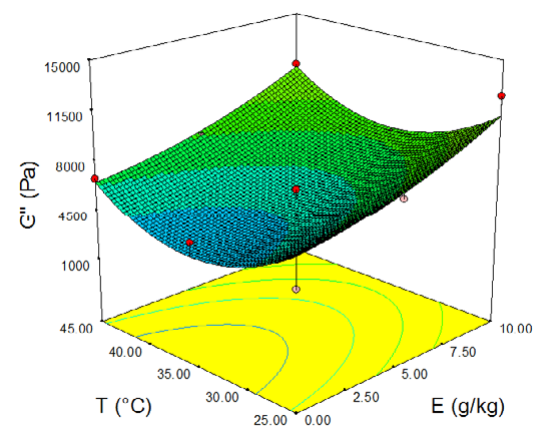

c

Figure 2: Response surface plots for the effects of temperature $\left({ }^{\circ} \mathrm{C}\right)$ and commercial enzyme concentration $(\mathrm{g} / \mathrm{kg})$ at different incubation times $(\mathrm{h})$ on $\mathrm{G}$ " $(\mathrm{Pa})$. $(2 \mathrm{a}) \mathrm{At}$ time $=1 \mathrm{~h},(2 \mathrm{~b})$ At time $=3 \mathrm{~h},(2 \mathrm{c})$ At time $=5 \mathrm{~h}$.

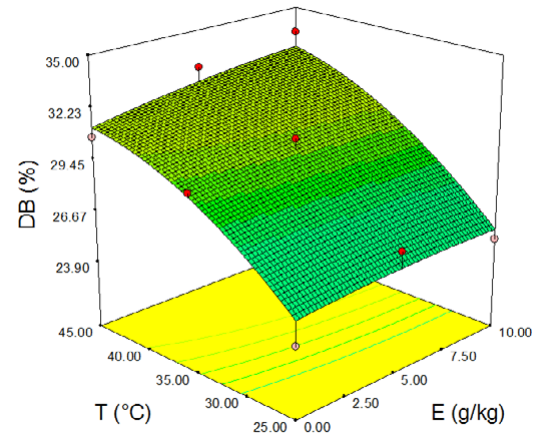

a

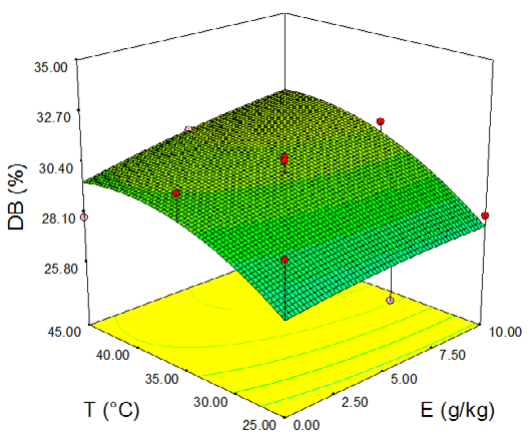

b

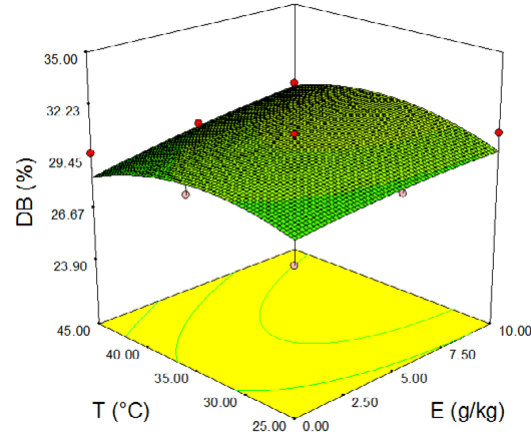

c

Figure 3: Response surface plots for the effects of temperature $\left({ }^{\circ} \mathrm{C}\right)$ and commercial enzyme concentration $(\mathrm{g} / \mathrm{kg})$ at different incubation times $(\mathrm{h})$ onDB $(\%)$. (3a) At time $=1 \mathrm{~h},(3 \mathrm{~b})$ At time $=3 \mathrm{~h},(3 \mathrm{c})$ At time $=5 \mathrm{~h}$.

After checking the normality of the data using a normal probability plot of the residuals and the difference between the observed values and those predicted from the regression, we found that the experimental points were normally distributed around the line, indicating that the normality assumption was satisfied.

ANOVA and regression analysis were used to examine the statistical significance of the terms and to check the model adequacy (Table 4).

It was suggested that for a good fitted model, the coefficient of determination $\left(\mathrm{R}^{2}\right)$ should not be less than $80 \%$. The lower values of $\mathrm{R}^{2}$ show the inappropriateness of the model to explain the relation between variables [48]. 


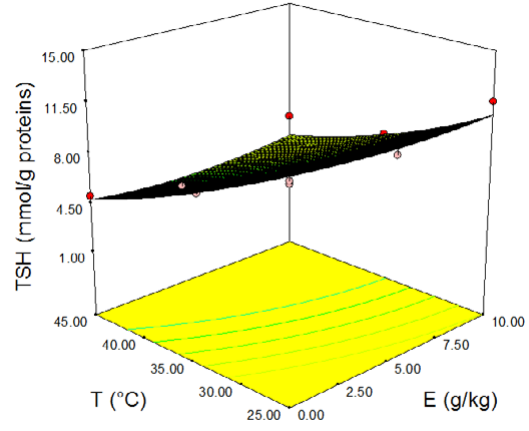

$\mathbf{a}$

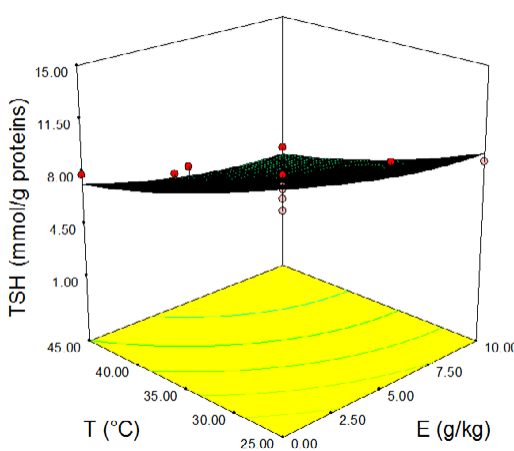

b

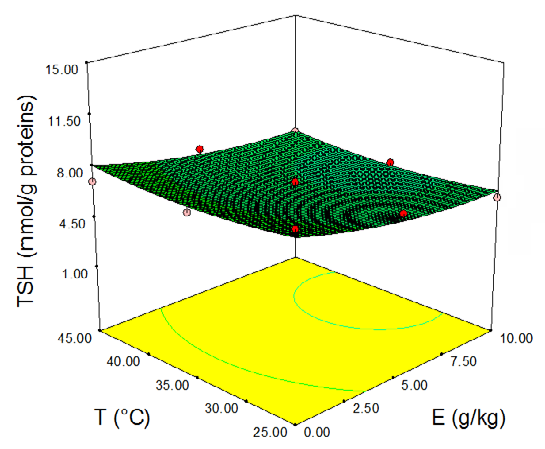

c

Figure 4: Response surface plots for the effects of temperature $\left({ }^{\circ} \mathrm{C}\right)$ and commercial enzyme concentration $(\mathrm{g} / \mathrm{kg})$ at different incubation times $(\mathrm{h})$ on TSH (mmol/g proteins). (4a) At time $=1 \mathrm{~h},(4 \mathrm{~b})$ At time $=3 \mathrm{~h},(4 \mathrm{c})$ At time $=5 \mathrm{~h}$.

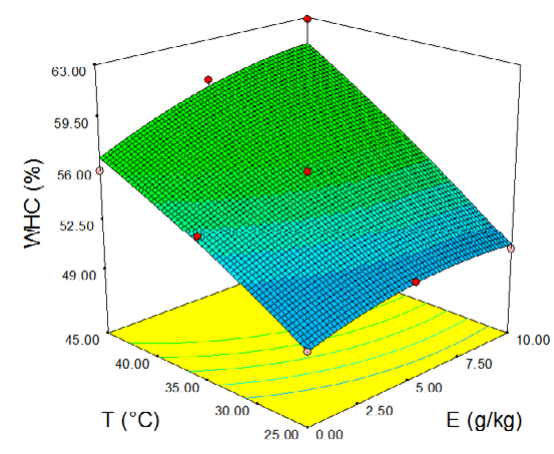

a

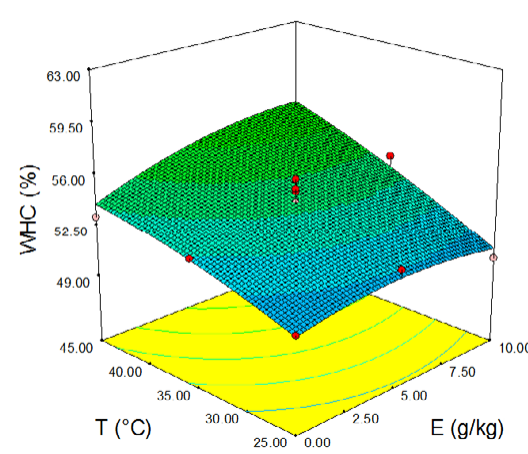

b

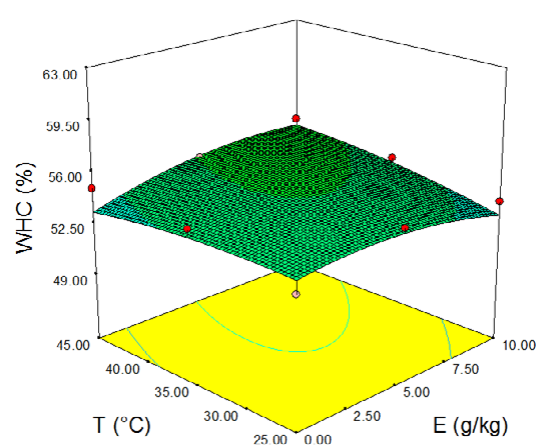

C

Figure 5: Response surface plots for the effects of temperature $\left({ }^{\circ} \mathrm{C}\right)$ and commercial enzyme concentration $(\mathrm{g} / \mathrm{kg})$ at different incubation times $(\mathrm{h})$ on WHC $(\%)$. $(5 \mathrm{a})$ At time $=1 \mathrm{~h},(5 \mathrm{~b})$ At time $=3 \mathrm{~h},(5 \mathrm{c})$ At time $=5 \mathrm{~h}$.

The $\mathrm{R}^{2}$ values for the regression model predicting the storage modulus $\mathrm{G}^{\prime}$, the loss modulus $\mathrm{G}^{\prime}$, DB content, TSH content and WHC were found to be $0.8824,0.9015,0.7845,0.9057$ and 0.8671 respectively, indicating a good suitability between the observed and predicted response values.

The lack of fit is an indication of the failure of a model representing the experimental data at which points were not included in the regression or variations in the models cannot be accounted for random error [49]. When a lack of fit is significant, the response predicted is discarded.

Data indicated the insignificance of the lack of fit of all dependent variables $\left(\mathrm{F}_{\mathrm{cal}}<\mathrm{F}_{\mathrm{tab}}\right)$ confirming that the quadratic model was valid for this study (Table 4).

Moreover, to validate the model, the plots of the residual versus the predicted values should present residuals scattered randomly around zero and did not reveal any outliers.

Our results (plots not shown), showed that all the values lie within the accepted range $(-3$ and +3$)$ [23] for all the response variables. Thus, all the model assumptions being satisfied, the variance analysis indicated that the model was valid.

When analysing the parity plots (plots not shown) showing the distribution of predicted values versus the actual ones of the storage modulus $\mathrm{G}^{\prime}$, the loss modulus $\mathrm{G}^{\prime}$, DB content, TSH content and WHC, it can be seen a satisfactory correlation between the experimental and predictive values since the points are clustered around the diagonal line which indicates a good agreement between the polynomial regression model and the experimental results.

\section{Optimization of conditions using the response surface methodology}

Based on the results, it was observed that the optimum region of enzyme activity of MTGase was obtained for an MTGase concentration of $10 \mathrm{~g} / \mathrm{kg}$ with $1 \mathrm{~h}$ of incubation at $45^{\circ} \mathrm{C}$ (Table 5). This means that the highest degree of fish protein cross-linking occurring during sardine surimi gel production was obtained under these conditions. From the models, it can be concluded that the optimal temperature for MTGase $\left(40^{\circ} \mathrm{C}\right.$ to $\left.45^{\circ} \mathrm{C}\right)$ is higher than that for endogenous TGase $\left(35^{\circ} \mathrm{C}\right.$ to $40^{\circ} \mathrm{C}$ ) extracted from sardine muscle, established in a preliminary study (data not shown), and is close to the optimal temperature $\left(50^{\circ} \mathrm{C}\right)$ for the catalysis of MTGase [50].

Finally, in order to compare the behaviour of the setting phenomenon with the addition of MTGase, Table 6 shows the results of related studies of surimi gels from different species. The optimal setting temperature and enzyme concentration for sardine were both higher than those reported for the other fish species. This could be explained 
Citation: Zaghbib I, Arafa S, Félix M, Hassouna M, Romero A (2016) Enhancement of the Gelling Properties of Sardine Surimi with Transglutaminase and Optimization of its Activity Using Response Surface Methodology. J Food Process Technol 7: 594. doi:10.4172/2157-7110.1000594

Page 7 of 8

\begin{tabular}{|c|c|c|c|c|c|c|c|}
\hline Response & $\mathbf{R}^{2}$ & p-value Prob $>F$ & F value & Lack of Fit & Adeq. Precision & Adj. $\mathbf{R}^{2}$ & Pred. $\mathbf{R}^{2}$ \\
\hline y1 & 0.8824 & $<0.0001$ & 16.67 & 0.1039 & 15.15 & 0.8295 & 0.7279 \\
\hline y2 & 0.9015 & $<0.0001$ & 20.35 & 0.2362 & 15.34 & 0.8572 & 0.7625 \\
\hline y3 & 0.7845 & $<0.0001$ & 8.09 & 0.2738 & 11.24 & 0.6876 & 0.4450 \\
\hline y4 & 0.9057 & $<0.0001$ & 1.33 & 0.2679 & 20.94 & 0.8632 & 0.7636 \\
\hline y5 & 0.8671 & $<0.0001$ & 14.50 & 0.1478 & 16.92 & 0.8073 & 0.6739 \\
\hline
\end{tabular}

Table 4: Statistical parameters measuring the correlation and significance of models.

\begin{tabular}{|c|c|c|c|c|c|c|c|c|c|}
\hline \multirow[t]{2}{*}{ Test } & \multicolumn{3}{|c|}{ Process variables } & \multicolumn{5}{|c|}{ Predicted values } & \multirow[t]{2}{*}{ Desirability } \\
\hline & $E$ & $T$ & $t$ & $G^{\prime}$ & G" & DB & TSH & WHC & \\
\hline 1 & 10 & 45 & 1 & 59103 & 14141 & 32.77 & 2.05 & 61.12 & 0.928 \\
\hline 2 & 10 & 44.98 & 1.02 & 58747 & 14071 & 32.75 & 2.09 & 61.07 & 0.925 \\
\hline 3 & 10 & 44.82 & 1 & 58248 & 13960 & 32.74 & 2.11 & 61.04 & 0.923 \\
\hline
\end{tabular}

Table 5: Predicted optimum conditions for optimal MTGase activity.

\begin{tabular}{|c|c|c|c|c|}
\hline \multirow[t]{2}{*}{ Fish species } & \multicolumn{3}{|c|}{ Setting conditions } & \multirow[t]{2}{*}{ References } \\
\hline & Enzyme concentration (g/kg) & Temperature $\left({ }^{\circ} \mathrm{C}\right)$ & Incubation time (h) & \\
\hline $\begin{array}{c}\text { Alaska pollock } \\
\text { Theragra chalcogramma }\end{array}$ & 2 & 25 & 3 & Lee et al. [36] \\
\hline $\begin{array}{l}\text { Striped mullet } \\
\text { Mugil cephalus }\end{array}$ & 5 & 34.5 & 1 & Ramírez et al. [39] \\
\hline $\begin{array}{c}\text { Silver carp } \\
\text { Hypophthalmichthys molitrix }\end{array}$ & 8.8 & 39.6 & 1 & Ramírez et al. [40] \\
\hline $\begin{array}{c}\text { Sardine } \\
\text { Sardina pilcharus }\end{array}$ & 10 & 45 & 1 & The present study \\
\hline
\end{tabular}

Table 6: Comparison of optimal setting conditions of surimi gels from different fish species.

by the optimal temperature for setting being related to fish habitat temperature [51] and to the thermal stability of myosin in each fish species [52]. Furthermore, the cross-linking reaction induced by TGase occurs when protein molecules and the enzyme become associated in a highly-oriented and conformation-dependent fashion during the catalytic process [53]. Therefore, optimal enzyme concentrations and setting temperatures should be determined for each type of surimi to obtain the best gel quality.

\section{Conclusion}

In conclusion, the application of the RSM is a practical and effective tool in optimizing the parameters of transglutaminase activity in sardine surimi gel during setting.

The enzymatic treatment considerably ameliorated the gelling properties of the surimi gel obtained, due to the high-molecular-weight polymers formed during the cross-linking reaction induced by TGase.

Results suggest that setting is dependent on enzymatic activity and protein denaturation/aggregation, both processes occurring during the setting phenomenon. Hence, MTGase can be considered a useful additive for the production of surimi gels from sardine. Sardine surimi gel was predicted to have optimal properties for setting under the following conditions: $45^{\circ} \mathrm{C} / 1 \mathrm{~h}$ using $10 \mathrm{~g}$ of microbial TGase/ $\mathrm{kg}$ of surimi. All the mathematical models derived from the various responses were found to be a good fit to predict the data.

\section{Acknowledgements}

The authors would like to thank the Tunisian Ministry of Higher Education and Scientific Research (MHESR) for the financial support and express their sincere thanks to the University of Sevilla, Faculty of Chemistry for the valorous technical support.

\section{References}

1. Mao L, Wu T (2007) Gelling properties and lipid oxidation of kamaboko gels from grass carp (Ctenopharyngodon idellus) influenced by chitosan. J Food Eng 82: 128-134.
2. Herranz B, Tovar CA, Borderias AJ, Moreno HM (2013) Effect of high-pressure and/or microbial transglutaminase on physicochemical, rheological and microstructural properties of flying fish surimi. Innov Food Sci Emerg 20: 24-33.

3. Wu J, Li CY, Ho ML, Jiang ST (2000) Quality improvement of mackerel surim with NADPH-sulfite reductase from Escherichia coli. J Food Sci 68: 1400-1403.

4. Chen HH, Chiu EM, Huang JR (1997) Colour and gel-forming properties of horse mackerel (Trachurus japonucus) as related to washing conditions. J Food Sci 62: 985-991.

5. Kelleher SD, Hultin HO, Wilhelm KA (1994) Stability of mackerel surimi prepared under lipid-stabilizing processing conditions. J Food Sci 59: 269-271.

6. Niwa E (1992) Chemistry of surimi gelation: Surimi technology. In: Lanier TC, Lee CM (eds): Marcel Dekker, New York, USA.

7. Sikorski ZE, Kolakowska A, Burt JR (1990) Post-harvest biochemical and microbial changes: Seafood: Resources, nutritional composition and preservation. CRC Press, Florida.

8. Spinelli J, Dassow JA (1982) Fish proteins: their modification and potential uses in the food industry: Chemistry and biochemistry of marine food products. AVI Publishing Company, Westport, CT.

9. Haard NF, Simpson BK, Pan BS (1994) Sarcoplasmic proteins and other nitrogenous compounds: Seafood proteins. Chapman \& Hall, New York, USA.

10. Anon (1998) Basic properties of transglutaminase (informative bulletin). Teaneck, Ajinomoto, USA.

11. Chanarat S, Benjakul S, Kittiku HA (2012) Comparative study on protein crosslinking and gel enhancing effect of microbial transglutaminase on surimi from different fish. J Sci Food Agr 92: 844-852.

12. Ana LCG, Silvana PGF (2015) Action of microbial transglutaminase (MTGase) in the modification of food proteins: A review. Food Chem 171: 315-322.

13. Asagami T, Ogiwara M, Wakameda A, Noguchi SF (1995) Effect of microbial transglutaminase on the quality of frozen surimi made from various kinds of fish species. Fisheries Sci 61: 267-272.

14. DeJong GAH, Koppelman SJ (2002) Transglutaminase catalyzed reactions: Impact on food applications. J Food Sci 67: 2798-2806.

15. Visessanguan W, Benjakul S, Tanaka M (2003) Effect of microbia transglutaminase on rheological properties of oxidised and non-oxidised natural actomyosin from two species of bigeye snapper. J Sci Food Agr 83: 105-112. 
Citation: Zaghbib I, Arafa S, Félix M, Hassouna M, Romero A (2016) Enhancement of the Gelling Properties of Sardine Surimi with Transglutaminase and Optimization of its Activity Using Response Surface Methodology. J Food Process Technol 7: 594. doi:10.4172/2157-7110.1000594

16. Lanier TC (2000) Surimi gelation chemistry: Surimi and Surimi Seafood. Marcel Dekker, New York.

17. Seki N, Uno H, Lee NH, Kimura I, Toyoda K, et al. (1990) Transglutaminase activity in Alaska pollack muscle and surimi and its reaction with myosin B. Nippon Suisan Gakk 56: 125-132.

18. Tsukamasa Y, Sato K, Shimizu Y, Imai C, Sugiyama M, et al. (1993) $\varepsilon-(Y-$ glutamyl) lysine cross-link formation in sardine myofibril sol during setting at $25^{\circ} \mathrm{C}$. J Food Sci 58: 785-787.

19. Gauche C, Vieira JTC, Ogliari PJ, Bordignon-Luiz MT (2008) Cross-linking of milk whey proteins by transglutaminase. Process Biochem 43: 788-794.

20. Pinterits A, Arntfield SD (2008) Improvement of canola protein gelation properties through enzymatic modification with transglutaminase. LWT-Food Sci Technol 41: 128-138.

21. Rodriguez-Nogales JM (2006) Enhancement of transglutaminase-induced protein cross-linking by preheat treatment of cows' milk: a statistical approach. Int Dairy J 16: 26-32.

22. Abdullah AZ, Salamatinia B, Kamaruddin AH (2009) Application of response surface methodology for the optimization of $\mathrm{NaOH}$ treatment on oil palm frond towards improvement in the sorption of heavy metals. Desalination 244: 227-238.

23. Roriz MS, Osma JF, Teixeira JA, Couto SR (2009) Application of response surface methodological approach to optimise Reactive Black 5 decolouration by crude laccase from Trametes pubescens. J Hazard Mater 169: 691-696.

24. Chaijan M, Benjakul S, Visessanguan W, Faustman C (2004) Characteristics and gel properties of muscles from sardine (Sardinella gibbosa) and mackerel (Rastrelliger kanagurta) caught in Thailand. Food Res Int 37: 1021-1030.

25. Xiong YL, Blanchard SP (1994) Dynamic gelling properties of myofibrilla protein from skeletal muscles of different chicken parts. J Agr Food Chem 42 $670-674$

26. Thannhauser TW, Konishi Y, Scheraga HA (1987) Analysis for disulfide bonds in peptides and proteins. Method Enzymol 143: 155-161.

27. Ellman GL (1959) Tissue sulfhydryl groups. Arch Biochem Biophys 82: 70-77.

28. Sang-Keun J, II-Suk K, Su-Jung K, Ki-Jong J, Yung-Joon C, et al. (2007) Effect of muscle type and washing times on physico-chemical characteristics and qualities of surimi. J Food Eng 81: 618-623.

29. Box GEP, Hunter WG, Hunter JS (1988) Estadística para Investigadores. Barcelona: Reverté.

30. Popov S, Rankovi J, Dodić J, Dodić S, Jokić A, et al. (2010) Bioethano production from raw juice as intermediate og sugar beet processing: $A$ response surface methodology approach. Food Technol Biotech 48: 376- 383.

31. Rathakrishnan P, Nagarajan P, Rajesh Kannan R (2011) Response surface optimization of medium composition for protease production by Bacillus subtilis using cassava waste. Chem Ind Chem Eng Q 17: 215-222.

32. Flander L, Salmenkallio-Marttila M, Suortti T, Auti K (2007) Optimization of ingredients and baking process for improved wholemeal oat bread quality. LWT-Food Sci Technol 40: 860-870.

33. Vieira GS, Pereira LM, Hubinger MD (2012) Optimization of osmotic dehydration process of guavas by response surface methodology and desirability function. Int J Food Sci Tech 47: 132-140.

34. Lanier TC (1992) Measurement of surimi composition and functional properties: Surimi technology. Marcel Dekker, New York.

35. Jiang ST (2000) Enzymes and their effects on seafood texture: Seafood enzymes: utilization and influence on postharvest seafood quality. Marce Dekker, New York.

36. Lee HG, Lanier TC, Hamann DD, Knopp JA (1997) Transglutaminase effects on low temperature gelation of fish protein sols. J Food Sci 62: 20-24.

37. An H, Peters MY, Seymour TA (1996) Roles of endogenous enzymes in surim gelation. Trends Food Sci Tech 7: 321-327.

Citation: Zaghbib I, Arafa S, Félix M, Hassouna M, Romero A (2016) Enhancement of the Gelling Properties of Sardine Surimi with Transglutaminase and Optimization of its Activity Using Response Surface Methodology. J Food Process Technol 7: 594. doi:10.4172/2157-7110.1000594
38. Lee N, Park JW (1998) Calcium compounds to improve gel functionality of Pacific whiting and Alaska pollock surimi. J Food Sci 63: 969-974.

39. Ramírez JA, Santos IA, Morales OG, Morrissey MT, Vázquez M, et al (2000) Surimi gels from striped mullet (Mugil cephalus) employing microbial transglutaminase. Food Chem 70: 443-449.

40. Ramírez JA, Santos IA, Morales OG, Morrissey MT, Vázquez M, et al. (2000) Application of microbial transglutaminase to improve mechanical properties of surimi from silver carp. Ciencia Tecnol Alime 3: 21-28.

41. Park JD, Park JW (2007) Extraction of sardine myoglobin and its effect on gelation properties of Pacific Whiting surimi. J Food Sci 72: 202-207.

42. Damodaran S (2010) Aminoácidos, peptídeos e proteínas: Química de alimentos de Fennema. Artmed, Porto Alegre.

43. Motoki M, Kumazaw $Y(2000)$ Recent research trends in transglutaminase technology for food processing. Food Sci Technol Res 6: 151-160.

44. Benjakul S, Visessanguan W, Ishizaki S, Tanaka M (2001) Differences in gelation characteristics of natural actomyosin from two species of bigeye snapper, Priacanthus tayenus and Priacanthus macracanthus. J Food Sci 66 : 1311-1318.

45. Han M, Zhang Y, Fei Y, Xu X, Zhou G (2009) Effect of microbial transglutaminase on NMR relaxometry and microstructure of pork myofibrillar protein gel. Eur Food Res Technol 228: 665-670.

46. Min B, Green BW (2008) Use of microbial transglutaminase and nonmeat proteins to improve functional properties of low $\mathrm{NaCl}$, phosphate-free patties made from channel catfish (Ictalurus punctatus) belly flap meat. J Food Sci 73: $218-226$

47. Priscilla NR, Estela MF, de Sá Vívian MB, Marilde TBL (2011) Optimization of microbial transglutaminase activity in ice cream using response surface methodology. LWT-Food Sci Technol 44: 29-34

48. Koocheki A, Taherian AR, Razavi SMA, Bostan A (2009) Response surface methodology for optimization of extraction yield, viscosity, hue and emulsion stability of mucilage extracted from Lepidium perfoliatum seeds. Food Hydrocolloïds 23: 2369-2379.

49. Montgomery DC (2001) Design and analysis of experiments (5thedn). Wiley \& Sons, New York.

50. Ajinomoto $X$ (1998) Basic properties of transglutaminase, Brochure from the company, Teaneck, NJ.

51. Morales OG, Ramirez JA, Vivanco DI, Vázquez M (2001) Surimi of fish species from the gulf of Mexico: evaluation of the setting phenomenon. Food Chem 75: $43-48$

52. Benjakul S, Chantarasuwan C, Visessanguan W (2003) Effect of medium temperature setting on gelling characteristics of surimi from some tropical fish. Food Chem 82: 567-74.

53. Gorman JJ, Folk JE (1981) Structural features of glutamine substrates for transglutaminase: specificity of human factor XIII a and the guinea pig liver enzyme toward synthetic peptides. J Biol Chem 256: 2712-2715.

\section{OMICS International: Open Access Publication Benefits \&}

\section{Features}

Unique features:

Increased global visibility of articles through worldwide distribution and indexing

Showcasing recent research output in a timely and updated manner

Special issues on the current trends of scientific research

Special features:

$700+$ Open Access Journals

$50,000+$ editorial team

Rapid peer review process

Quality and quick editorial, review and publication processing

Indexing at major indexing services

Sharing Option: Social Networking Enabled for better prominence and citations

Authors, Reviewers and Editors rewarded with online Scientific Credits

Best discounts for your subsequent articles

Submit your manuscript at: http://www.omicsgroup.org/iournals/submission 